Jurnal Sistim Informasi dan Teknologi
https: //jsisfotek . org/index . php

\title{
Identifikasi dalam Penentuan Prioritas Usulan Kenaikan Jabatan Fungsional Pegawai Menggunakan Metode TOPSIS
}

\author{
Zulvitri $^{1 凶}$, Sarjon Defit ${ }^{2}$, Sumijan $^{3}$ \\ ${ }^{1,2,3}$ Universitas Putra Indonesia YPTK Padang \\ zu1vitridavid@gmai1.com
}

\begin{abstract}
Padang State Polytechnic (PNP) is one of the state universities located in the city of Padang, which has 39 Learning Laboratory Institution Functional Officials, who were later told by PLP. PLP is a Civil Servant (PNS) who is given the task, responsibility, authority and right to carry out activities in the field of learning laboratory management. The problem that occurs is that the PLP does not know the exact time of application for promotion and functional positions of each. Some of the difficulties occur in managing the sub-division of personnel in finding archives. This article is always increasing and accumulating each period of acceptance. So this research aims to process this staffing data to make it easier and to accelerate the promotion process. The method used is the Decision Support System (DSS) in identifying priorities for proposals for functional promotion. The DSS method used is Technique For Order Preference By Similarity to Ideal Solution (TOPSIS). The results of this study have the reliability in considering the shortest distance to the positive ideal solution and also the longest distance to the negative ideal solution. The alternatives and criteria used in this study consisted of 5 alternatives and 3 criteria. The value of ideal positive and negative solutions has a maximum value of $\mathrm{K} 1$ which is $0.66, \mathrm{~K} 2$ is $0.022, \mathrm{~K} 3$ is 0.05 and a minimum value of $\mathrm{K} 1$ is $0.1, \mathrm{~K} 2$ is $0.017, \mathrm{~K} 3$ is 0.022 . The highest score in ranking is 2 people with a score of 1 and the lowest is 1 person with a score of 0.0008 . So this research is very helpful in identifying promotion priorities appropriately.
\end{abstract}

Keywords: Decision Support System, Functional Position, Employee Work Objectives, Employee, TOPSIS.

\begin{abstract}
Abstrak
Politeknik Negeri Padang (PNP) merupakan salah satu perguruan tinggi negeri yang terdapat di Kota Padang, yang mana memiliki 39 Pejabat Fungsional Pranata Laboratorium Pembelajaran yang berikutnya dituturkan PLP. PLP merupakan pegawai Pegawai Negeri Sipil (PNS) yang diberi tugas, tanggung jawab, wewenang serta hak buat melaksanakanaktivitas di bidang pengelolaan Laboratorium Pembelajaran.Masalah yang terjadi adalahPLP tidak mengetahui dengan tepat waktu pengajuan kenaikan pangkat dan jabatan fungsional masing-masing. Sebagian terjadikesulitan dalam pengelola pada sub bagian kepegawaian dalam mencari arsip. Arisip ini selalu bertambah dan menumpuk setiap periode penerimaan. Maka penelitian ini bertujuan mengolah data kepegawaian ini dalam mepermudah dan mempercepat proses kenaikan jabatan. Metode yang digunakan adalah Sistem Pendukung Keputusan (SPK) dalam mengindentifikasi dalam penentuan prioritas usulan kenaikan jabatan fungsional. Metode SPK yang digunakan adalah Technique For Order Preference By Similarity to Ideal Solution (TOPSIS).Hasil dari penelitian ini memiliki kehandalan dalam mempertimbangkan jarak terpendek pada solusi ideal positif dan juga jarak terpanjang pada solusi ideal negative. Alternatif dan kriteria yang digunakan pada penelitian ini terdiri dari 5 alternatif dan 3 kriteria.Nilai solusi ideal positive dan negative memiliki nilai maximal K1 yaitu 0.66, K2 yaitu $0.022, \mathrm{~K} 3$ yaitu 0.05 dan nilai minimal $\mathrm{K} 1$ yaitu $0.1, \mathrm{~K} 2$ yaitu $0.017, \mathrm{~K} 3$ yaitu 0.022 . Nilai tertinggi dalam perengkingan yaitu 2 orang dengan nilai 1 dan terendah adalah 1 orang dengan nilai 0.0008 . Sehingga penelitian ini sangat membantu dalam mengidentifikasi prioritas kenaikan jabatan dengan tepat.
\end{abstract}

Kata kunci: Sistem Pendukung Keputusan, Jabatan Fungsional, Sasaran Kerja Pegawai, Kepegawaian, TOPSIS.

(c) 2021 JSisfotek

\section{Pendahuluan}

Politeknik Negeri Padang merupakan salah satu perguruan tinggi yang ada di kota padang, yang mana mempunyai 39 Pejabat Fungsional Pranata Laboratorium Pendidikan yang selanjutnya disebut PLP. PLP adalah pegawai PNS yang diberi tugas, tanggung jawab, wewenang dan hak untuk melakukan kegiatan di bidang pengelolaan Laboratorium pendidikan. Adapun permasalahan yang dikeluhkan di Politeknik Negeri Padang, yang mana plp sering lupa bahkan tidak tahu kapan mengajukan kenaikan pangkat dan jabatanfungsionalnya. Sebagian ada juga yang menanyakan persyaratan-persyaratan apa saja masih kurang dari mereka.

Hal ini menjadi kesulitan tersendiri bagi pengelola sub bagian kepegawaian untuk mencari arsip atau dokumen yang sudah bertumpuk sehingga pengelola sub bagian kepegawaian akan tersita waktunya. Bersamaan dengan adanya permasalahan tersebut, dibutuhkan sebuah sistem yang yang dapat mempermudah dalam pekerjaan.Sistem pendukung keputusan merupakan sistem informasi berbasis komputer yang bersifat interaktif, fleksibel dan mudah beradaptasi yang dirancang khusus untuk membantu 
manajemen masalah yang tidak terstruktur untuk meningkatkan pengambilan keputusan [1].

Sistem pendukung keputusan dapat diartikan sebagai sistem yang dirancang untuk digunakan dalam mendukung manajemen dalam pengambilan keputusan sebagai alat yang dapat digunakan dalam pengambilan keputusan bagi pengambil keputusan. Keputusan yang ditawarkan oleh sistem pendukung keputusan cenderung cepat dan secara kuantitatif merupakan pilihan terbaik berdasarkan tingkat kepentingan/bobot kriteria yang diberikan oleh manajemen sebagai pengambil keputusan [2].

Salah satu metode yang bisa digunakan buat Sistem Pendukung Keputusan adalah dengan menggunakan metode Technique For Order Preference By Similarity to Ideal Solution (TOPSIS). Metode ini memiliki kehandalan karena mempertimbangkan jarak terpendek pada solusi ideal positif serta pula jarak terpanjang penyelesaian ideal negative [3].

Penelitian terdahulu yang menerapkan metode TOPSIS menggunakan beberapa kriteria yaitu perencanaan, pembelajaran, evaluasi dan pelatihan. Hasil perankingan yang diperoleh dari pengujian perhitungan bila alternative Tutor $F$ yakni tutor terbaik dengan hasil perhitungan 0, 804 bila dibanding dengan kedua belas alternatif yang lain [4]. Metode TOPSIS mempunyai tingkatan keakurasian informasi $85 \%$ dari ke 3 belas alternatif serta bisa digunakan selaku pendukung keputusan pimpinan untuk membuat saran peningkatan jenjang karier tutor [5]. Dengan menerapkan tata cara TOPSIS bisa menunjang pihak akademik bagian kepegawaian dalam memantau jenjang jabatan fungsional ataupun pangkat dosen, sehingga bisa menegaskan dosen apabila telah waktunya untuk melakukan pengajuan kenaikan jabatan fungsional dan pangkat dosen [6].

Penelitian selanjut yang meneliti penilaian kinerja pegawai pada kantor pemerintahan Desa Maja Baru menggunakan metode TOPSIS dalam mengambil suatu keputusan dan sebagai dasar perhitungan yang berguna untuk pengambilan keputusan [7]. Penelitian yang memanfaatkan metode TOPSIS sebagai Sistem Pendukung Keputusan menggunakan metode Penilaian Kinerja Pegawai. Menerapan metode topsis dalam menentuan skala prioritas Rehabilitasi jaringan irigasi daerah Ketiat B Bengkayang [8]. Penelitian selanjutnya melakukan penentuan kenaikan jabatan pegawai negeri sipi dengan 5 alternatif dan 7 kriteria dengan menghasilkan Nilai V2 membuktikan nilai terbanyak sehingga alternatif A2 merupakan alternative yang terpilih selaku alternatif terbaik [9].

Pemilihan perguruan tinggi seharus disesuaikan antara kriteria perguruan tinggi dengan kebutuhan serta keahlian dari calon mahasiswa. Penelitian ini memakai model eksperimen tentang sistem pendukung keputusan memilih perguruan tinggi memakai metode TOPSIS, Penelitian ini buat menolong calon mahasiswa dalam seleksi melanjutkan studi [10]. Penelitian Selanjutnya Penilaian Kinerja Karyawan sebagai Promosi pekerjaan di Apartemen Senayan Jakarta dengan memanfaatkan Metode Topsis. Pemanfaatan penelitian ini merupakan buat memilah mutu kinerja karyawan buat promosi jabatan bersumber pada kriteria yang didetetapkan. Bersumber pada ilustrasi informasi yang digunakan sebanyak 14 karyawan, hasil penelitian dilihat pada rangking [11].

University Entrepreneurship Center Identity (UECI) melakukan penelitian dalam menentukan faktor-faktor UECI. Faktor dirangking dengan menggunakan metode TOPSIS. Hasil TOPSIS mengungkapkan bahwa para ahli di UECs percaya bahwa ada delapan faktor prioritas tinggi, yaitu inovasi, interaksi industri, menghasilkan lulusan berkualifikasi tinggi, prokeaktifan, menarik wirausaha fakultas, kerja sama tim, konsultasi, dan pengambilan risiko [12]. Dengan penerapan Metode TOPSIS di dukungan keputusan dalam pemilihan file universitas swasta terbaik di Kota Medan mampu memberikan hasil yang optimal berdasarkan kriteria yang telah ditentukan. Proses perhitungan yang dilakukan dengan menggunakan Metode TOPSIS didapatkan peringkat terbaik institusi di Kota Medan dan nilai terbaik didapat adalah nilai tertinggi, yaitu A [13]. Penelitian selanjutnya mengidentifikasi mobil SUV terbaik di antara empat SUV yang kira-kira berada di bawah segmen yang sama \&memiliki spesifikasi teknis yang berbeda. Kami telah menyelesaikannya empat parameter sebagai Harga Ex-Showroom (dalam INR), Bahan Bakar Ekonomi (dalam KMPL), Kapasitas Mesin (dalam cc) dan Tempat Duduk diperoleh bahwa Renault Kwid Climber adalah pilihan terbaik yang tersedia dipasar di antara alternatif yang disajikan pada bobot yang ditetapkan [14]. Penerapan Metode trusbase dengan TOPSIS untuk Penentuan prioritas pembangunan di Kabupaten Merangin dapat digunakan. Metode ini mampu menentukan prioritas pembangunan dengan peresentase $90 \%$ hasilnya lebih akurat [15]. Penelitian selanjutnya metode topsis bisa di gunakan sebagai acuan dalam menentukan penentuan walikelas terbaik. Peneliti membuat aplikasi dengan cara cara menginput data melalui admin kemudian menghasilkan nilai output melalui proses topsis [16]. Penelitian selanjutnya menggunakan kriteria dalam pemilihan karyawan terbaik adalah: pekerjaan tanggung jawab, disiplin kerja, kualitas kerja, dan perilaku. Proses perhitungan pada aplikasi web yang dirancang, dari Proses perhitungan yang dilakukan dipekerjakan dengan nama Herbert karyawan terbaik [17]. Penelitian selanjutnya topsis digunakan untuk menentukan peringkat faktor yang mempengaruhi kesehatan finansial dan kemanjuran diri. Faktor-faktor yang mempengaruhi kesehatan finansial diberi nama faktor organisasi, faktor administrasi-ekonomi, faktor hukum-hukum, faktor sosial, kepribadian faktor, faktor regulasi dan faktor informasi. Unsur -unsur yang mempengaruhi efikasi diri individu faktor, faktor organisasi dan faktor manajemen diberi nama [18]. Penelitian selanjutnya Penilaian kinerja pegawai honorer sebagai sampel dari data penilaian kinerja 
pegawai seperti bahan pertimbangan kelanjutan hubungan kerjasama untuk anggaran masa depan. Komponen penilaian kinerja pegawai dilakukan pada 10 pegawai honorer sebagai sampel data penilaian kinerja pegawai sebagai bahan pertimbangan kelanjutan kegiatan hubungan kerjasama untuk anggaran masa depan. bobot yang sangat bagus, bagus, dan cukup bagus dari 10 orang karyawan Dikategorikan menurut kinerja appraisal, diperoleh nilai Joko Suprapto $=0,8394$ dan Nilai Suhendra $=$ 0,7862 kedua pegawai honorer tersebut dikategorikan dengan penilaian sangat baik kinerja [19]. Penelitian selanjutnya menentukan peningkatan mutu pekerja dengan topsis dalam perusahaan dengan mengunakan 14 kriteria serta melihat tingkat kinerja dari semua karyawan yang ada yang menghasilkan keputusan hasil perengkingan 1 dengan nilai 0,955203 sebagai karyawan terbaik [20].

\section{Metodologi Penelitian}

Metode penelitian merupakan tata cara ataupun langkah-langkah sistematis serta terstruktur yang digunakan dalam sebuah kegiatan penelitian untuk menjawab pertanyaan dari rumusan masalah yang sudah dibuat. Metode penelitian dibuat untuk membantu penyelesaian masalah agar lebih terarah dalam mencapai tujuan penelitian. Pada metode penelitian terdapat gambaran tentang prosedur atau tahapan-tahapan yang harus ditempuh, waktu penelitian, sumber data dan cara mendapatkan data tersebut sehingga bisa dianalisis dan diolah.Penelitian ini bertujuan untuk menerapkan TOPSIS sebagai Sistim Penunjang Keputusan (SPK) dalam melakukan proses identifikasi prioritas usulan kenaikan jabatan fungsional pegawai. Hasil dari penelitian ini diharapkan dapat memudahkan dalam mengidentifikasi Pegawai Pranata Laboratorium Pendidikan (PLP) yang memenuhi kriteria untuk usulan kenaikan jabatan fungsional di Politeknik Negeri Padang dengan menggunakan metode TOPSIS. Kerangka kerja adalah langkah-langkah dalam penelitian yang akan dilakukan untuk menyelesaikan suatu masalah yang akan dibahas. Tujuan membuat kerangka kerja adalah untuk membuat tahapantahapan yang akan dilakukan dalam penelitian. Setiap tahapan dilakukan sesuai dengan perencanaan. Adapun kerangka kerja penelitian yang dilakukan oleh penulis dapat dilihat pada Gambar 1 .

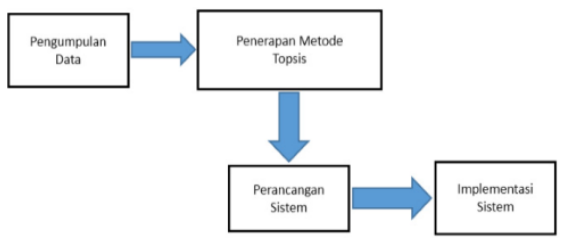

Gambar 1. Kerangka Kerja Penelitian

\subsection{Pengumpulan Data}

Tujuan dari pengumpulan data adalah untuk menentukan kebutuhan dalam penelitian yaitu berupa data kriteria yang digunakan untuk menemukan alternatif mana yang menjadi prioritas.Pembobotan kriteria adalah penilaian dari data yang didapat dari masing-masing kriteria. Kemudian dibuat suatu tingkat kepentingan kriteria berdasarkan nilai bobot yang telah ditentukan.

\subsection{Jenis Data}

Data yang digunakan dalam penelitian ini adalah Daftar Nominatif Penilaian Prestasi Kerja Pegawai dan data Rekapitulasi Tenaga Fungsional Pranata Laboratorium Pendidikan (PLP) yang telah mengajukan angka kredit yang bersumber dari bagian Kepegawaian Politeknik Negeri Padang.

\subsection{Banyak Data}

Berdasarkan data yang telah dianalisa dan disesuaikan dengan literatur, maka data yang digunakan dalam penelitian dokumen Daftar Nominatif Penilaian Prestasi Kerja Pegawai dan data Rekapitulasi Tenaga Fungsional Pranata Laboratorium Pendidikan (PLP) yang telah mengajukan angka kredit dalam tiga tahun terakhir. Sampel data yang digunakan dalam perhitungan ada 5 data. Kriteria yang digunakan ada tiga kriteria yaitu Pangkat dan Golongan, Nilai SKP, dan Angka Kredit. Kriteria ini, tiga sub kriteria yang diberi nilai untuk mempermudah dalam perhitungan.Yang menjadi goal atau tujuan dalam penelitian adalah mencari indentifikasi usulan kenaikan jabatan pegawai fungsional.

\section{Hasil dan Pembahasan}

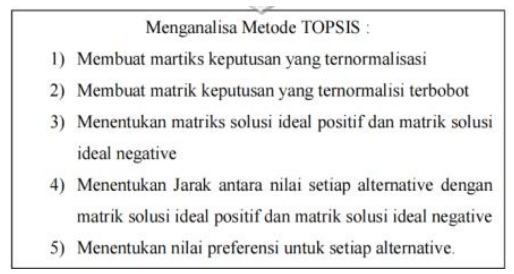

Gambar 2. Proses Metode TOPSIS

Hasil dari penerapan dengan memakai tata cara TOPSIS hendak merangking alternative bersumber pada prioritas nilai keakraban relatif sesuatu alternative terhadap pemecahan sempurna positif. Alternatif- alternatif yang sudah dirangking setelah itu dijadikan selaku rujukan untuk pengambil keputusan untuk memilah pemecahan terbaik yang diinginkan.Berikut struktur hirarki metode TOPSIS yang disajikan pada Gambar 3.

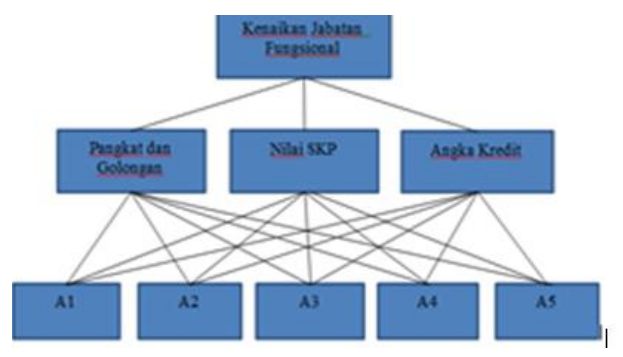

Gambar 3. Struktur Hirarki Metode TOPSIS

Pada Gambar 3 dapat dilihat struktur hirarki dari metode TOPSIS yangterdiri dari alternatif, kriteria, dan goal.Alternatif yang digunakan pada penelitian ini 
adalah data daftar nominatif penilaian prestasi kerja pegawai.

\subsection{Data Alternatif}

Ada Alternatif yang digunakan yang menjadi prioritas dilakukan terdapat pada Tabel 1 .

Tabel 1. Data Alternatif dan Kriteria

\begin{tabular}{lllll}
\hline No & Nama & $\begin{array}{l}\text { Pangkat dan } \\
\text { Golongan } \\
\text { Penata Muda Tk I/ }\end{array}$ & $\begin{array}{l}\text { Nilai } \\
\text { SKP }\end{array}$ & $\begin{array}{l}\text { Angka } \\
\text { Kredit }\end{array}$ \\
1 & ADR & III.b & 261.17 \\
2 & IND & Pengatur / II.C & 86.55 & 180 \\
3 & ALD & Penata Tk I / II.D & 92.00 & 221.95 \\
4 & SRI & Pengatur / II.C & 91.24 & 255 \\
5 & NOF & Penata / III.C & 92.00 & 255.8 \\
\hline
\end{tabular}

3.2 Penilaian Bobot Kepentingan Setiap Kriteria

Kriteria yang digunakan memiliki kepentingan atau bobot kriteria penilaian. Berikut data kepentingan atau bobot kriteria penilaian digunakan.

\section{Kriteria Pangkat dan Golongan}

Kriteria Pangkat dan Golongan memiliki penilaian. Berikut adalah nilai bobot kriteria Pangkat dan Golongan dapat disajikan pada Tabel 2.

Tabel 2 Kriteria Pangkat dan Golongan

\begin{tabular}{lll}
\hline Golongan & Nama Pangkat & Bobot \\
\hline & GOLONGAN I (Juru) & 1 \\
I A & Juru Muda & 1 \\
I B & Juru Muda Tingkat 1 & 1 \\
I C & Juru & 1 \\
I D & Juru Tingkat 1 & \\
& GOLONGAN II (Pengatur) & 2 \\
II A & Pengatur Muda & 2 \\
II B & Pengatur Muda Tingkat 1 & 2 \\
II C & Pengatur & 2 \\
II D & Pengatur Tingkat 1 & \\
& GOLONGAN III (Penata) & 3 \\
III A & Penata Muda & 3 \\
III B & Penata Muda Tingkat 1 & 3 \\
III C & Penata & 3 \\
III D & Penata Tingkat 1 & \\
& GOLONGAN IV (Pembina) & 4 \\
IV A & Pembina & 4 \\
IV B & Pembina Tingkat 1 & 4 \\
IV C & Pembina Utama Muda & 4 \\
IV D & Pembina Utama Madya \\
IV E & Pembina Utama & 4 \\
\hline
\end{tabular}

2 Kriteria Sasaran Kerja Pegawai

Kriteria Nilai Sasaran Kerja Pegawai (SKP) memiliki penilaian pada Tabel 3 .

Tabel 3. Nilai Kriteria Nilai SKP

\begin{tabular}{lll}
\hline Nilai SKP & Bobot & \\
\hline$<=50$ & Sangat Rendah & 1 \\
$<=60$ & Rendah & 2 \\
$<=75$ & Cukup & 3 \\
$<=90$ & Tinggi & 4 \\
$<90$ & Sangat Tinggi & 5 \\
\hline
\end{tabular}

\section{Kriteria Angka Kredit Jabatan}

Kriteria Angka Kredit Jabatan memiliki sub kriteria penilaian. Berikut adalah nilai dari sub kriteria pada kriteria Angka Kredit Jabatan.
Tabel 4. Nilai Kriteria Angka Kredit Jabatan

\begin{tabular}{cc}
\hline Angka Kredit Jabatan & Bobot \\
\hline $100-145$ & 1 \\
$150-200$ & 2 \\
$201-300$ & 3 \\
$301-350$ & 4 \\
\hline
\end{tabular}

\subsection{Data Alternatif}

Terdapat lima alternatif yang digunakan dalam menentukan prioritas usulan kenaikan jabatan fungsional pegawai. Data alternatif yang disajikan pada Tabel 5 .

Tabel 5. Tabel Data Alternatif

\begin{tabular}{cl}
\hline No & Nama \\
\hline 1 & ADR \\
2 & IND \\
3 & ALD \\
4 & SRI \\
5 & NOF \\
\hline
\end{tabular}

\subsection{Data Penilaian}

Nilai setiap kriteria merupakan hasil dari penginputan data alternatif Pranata Laboratorium Pendidikan (PLP) yang sudah dikonversikan berdasarkan nilai bobot kriteria yang telah ditentukan melalui proses perhitungan. Data penilaian dapat dilihat pada Tabel 6.

Tabel 6. Data Pranata Laboratorium Pendidikan (PLP) dengan Nilai dari Kriteria

\begin{tabular}{rllll}
\hline No & Alternatif & K1 & K2 & K3 \\
\hline 1 & ADR & 3 & 5 & 3 \\
2 & IND & 2 & 4 & 2 \\
3 & ALD & 2 & 5 & 3 \\
4 & SRI & 2 & 5 & 3 \\
5 & NOF & 3 & 5 & 3 \\
\hline
\end{tabular}

\subsection{Penilaian Alternatif Berdasarkan Kriteria}

Berikut adalah nilai dari setiap alternatif berdasarkan kriteria yang disajikan pada Tabel 7.

Tabel 7. Tabel Nilai Kasus

\begin{tabular}{lllll}
\hline No & Alternatif & K1 & K2 & K3 \\
\hline 1 & ADR & 3 & 5 & 3 \\
2 & IND & 2 & 4 & 2 \\
3 & ALD & 2 & 5 & 3 \\
4 & SRI & 2 & 5 & 3 \\
5 & NOF & 3 & 5 & 3 \\
\hline
\end{tabular}

Berdasarkan Tabel 7 diubah kedalam matrik keputusan $\mathrm{X}$ berikut:

$$
x=\begin{array}{rrr}
3 & 5 & 3 \\
2 & 4 & 2 \\
2 & 5 & 3 \\
2 & 5 & 3 \\
3 & 5 & 3
\end{array}
$$

3.6 Memberikan bobot Presentasi

Untuk menentukan bobot dari penentuan Kenaikan Pangkat Jabatan dibentuk dalam Tabel 8.

Tabel 8. Bobot nilai Kriteria untuk Kenaikan Pangkat Jabatan

\begin{tabular}{ccc}
\hline Kriteria & Bobot & Nilai \\
\hline C1 & Sangat Tinggi (ST) & 1 \\
C2 & Tinggi (T) & 0.5 \\
C3 & Sedang (S) & 0.2 \\
\hline
\end{tabular}


a. Normalisasi Matrik Keputusan

$r_{i j}=\frac{X_{i j}}{\sqrt{\sum_{i=1}^{m} X_{i j}^{2}}}$

Berdasarkan Persamaan 1, Maka akan dihitung nilai normalisasi alternatif berdasarkan Kriteria

$$
\begin{aligned}
& |x 1|=\sqrt{3^{2}+2^{2}+2^{2}+2^{2}+3^{2}} \\
& |x 1|=9+4+4+4+9=30 \\
& R_{11}=\frac{3}{30}=0.1 \\
& R_{12}=\frac{2}{30}=0.66 \\
& R_{13}=\frac{2}{30}=0.66 \\
& R_{14}=\frac{2}{30}=0.66 \\
& \mathrm{R}_{15}=\frac{3}{30}=0.1 \\
& |\mathrm{x} 2|=\sqrt{5^{2}+4^{2}+5^{2}+5^{2}+5^{2}} \\
& |x 2|=25+16+25+25+25=116 \\
& \mathrm{R}_{21}=\frac{5}{116}=0.043 \\
& \mathrm{R}_{22}=\frac{4}{116}=0.034 \\
& \mathrm{R}_{23}=\frac{5}{116}=0.043 \\
& \mathrm{R}_{24}=\frac{5}{116}=0.043 \\
& \mathrm{R}_{25}=\frac{5}{116}=0.043 \\
& |x 3|=\sqrt{3^{2}+2^{2}+3^{2}+3^{2}+3^{2}} \\
& |\mathrm{x} 3|=9+4+9+9+9=35 \\
& \mathrm{R}_{31}=\frac{9}{35}=0.25 \\
& \mathrm{R}_{32}=\frac{4}{35}=0.11 \\
& \mathrm{R}_{33}=\frac{9}{35}=0.25 \\
& \mathrm{R}_{34}=\frac{9}{35}=0.25 \\
& =\frac{9}{35}=0.25 \mathrm{R}_{35}
\end{aligned}
$$

Maka terbentuklah Matrix (R) ternormalisasi yang disajikan pada Tabel 9.

Tabel 9. Tabel Matrix (R)

\begin{tabular}{lllll}
\hline No & Alternatif $(\mathrm{R})$ & W1 & W2 & W3 \\
\hline 1 & ADR & 0.1 & 0.043 & 0.25 \\
2 & IND & 0.66 & 0.034 & 0.11 \\
3 & ALD & 0.66 & 0.043 & 0.25 \\
4 & SRI & 0.66 & 0.043 & 0.25 \\
5 & NOF & 0.1 & 0.043 & 0.25 \\
\hline
\end{tabular}

b. Menghitung matriks yang ternomalisasi yang terbobot (Y)
Untuk bobot yang sudah ditentukan, yaitu:

(W) : yij = wi.rij;

$\mathrm{y} 11=(0.1) *(1)=0.1$

$\mathrm{y} 12=(0.66) *(1)=0.66$

$\mathrm{y} 13=(0.66) *(1)=0.66$

$\mathrm{y} 14=(0.66) *(1)=0.66$

$\mathrm{y} 15=(0.1) *(1)=0.1$

$\mathrm{y} 21=(0.043) *(0.5)=0.022$

$\mathrm{y} 22=(0.034) *(0.5)=0.017$

$\mathrm{y} 23=(0.043) *(0.5)=0.022$

$\mathrm{y} 24=(0.043) *(0.5)=0.022$

y25 $=(0.043) *(0.5)=0.022$

$\mathrm{y} 31=(0.25) *(0.2)=0.05$

$\mathrm{y} 32=(0.11) *(0.2)=0.022$

$\mathrm{y} 33=(0.25) *(0.2)=0.05$

$\mathrm{y} 34=(0.25) *(0.2)=0.05$

$\mathrm{y} 35=(0.25) *(0.2)=0.05$

Sehingga hasilnya adalah:

Tabel 10. Matrik Ternormalisasi

\begin{tabular}{lllll}
\hline No & Alternatif & K1 & K2 & K3 \\
\hline 1 & ADR & 0.1 & 0.022 & 0.017 \\
2 & IND & 0.66 & 0.017 & 0.011 \\
3 & ALD & 0.66 & 0.022 & 0.017 \\
4 & SRI & 0.66 & 0.022 & 0.017 \\
5 & NOF & 0.1 & 0.022 & 0.011 \\
\hline
\end{tabular}

c. Menghitung Solusi Ideal (A+) dan Solusi Ideal (A)

$\mathrm{A}+=(\mathrm{y} 1+, \mathrm{y} 2+, \ldots \ldots \mathrm{yn}+)$

Maka nilai solusi ideal (A+) dan Solusi ideal (A-) adalah sebagai berikut:

Tabel 11. Solusi Ideal

\begin{tabular}{lllll}
\hline No & Alternatif & K1 & K2 & K3 \\
\hline 1 & ADR & 0.1 & 0.022 & 0.017 \\
2 & IND & 0.66 & 0.017 & 0.011 \\
3 & ALD & 0.66 & 0.022 & 0.017 \\
4 & SRI & 0.66 & 0.022 & 0.017 \\
5 & NOF & 0.1 & 0.022 & 0.017 \\
\hline & Max & 0.66 & 0.022 & 0.170 \\
& Min & 0.1 & 0.017 & 0.011 \\
\hline
\end{tabular}

d. Menghitung Jarak Solusi Ideal (D+) dan jarak Solusi Ideal (D-)

$$
\begin{aligned}
D_{i}^{+} & =\sqrt{\sum_{j}^{n}=1\left(y_{j}^{+}-y_{i j}\right) 2 i=1,2, \ldots, m} \\
D_{1}^{+} & =\sqrt{(0.1-0.66)^{2}+(0.022-0.022)^{2}+(0.05-0.05)^{2}} \\
& =0.3136+0+0=0.3136 \\
D_{2}^{+} & =\sqrt{(0.66-0.66)^{2}+(0.017-0.022)^{2}+(0.022-0.05)^{2}} \\
& =0+0.00002+0.0008=0.00082
\end{aligned}
$$

$D_{3}^{+}=\sqrt{(0.66-0.66)^{2}+(0.022-0.022)^{2}+(0.05-0.05)^{2}}$ 


$$
\begin{aligned}
& =0+0+0=0 \\
D_{4}^{+} & =\sqrt{(0.66-0.66)^{2}+(0.022-0.022)^{2}+(0.05-0.05)^{2}} \\
& =0+0+0=0 \\
D_{5}^{+} & =\sqrt{(0.1-0.66)^{2}+(0.022-0.022)^{2}+(0.022-0.05)^{2}} \\
& =0.0005+0+0.0008=0.0013 \\
D_{i}^{-} & =\sqrt{\sum_{j}^{n}=1\left(y_{j}^{-}-y_{i j}\right) 2 i=1,2, \ldots, m} \\
D_{1}^{-} & =\sqrt{(0.1-0.1)^{2}+(0.022-0.017)^{2}+(0.05-0.022)^{2}} \\
= & +0.00002+0.0008=0.00082 \\
D_{2}^{-} & =\sqrt{(0.66-0.1)^{2}+(0.017-0.017)^{2}+(0.022-0.022)^{2}} \\
= & 0.3136+0+0=0.3136 \\
D_{3}^{-}= & \sqrt{(0.66-0.1)^{2}+(0.022-0.017)^{2}+(0.05-0.022)^{2}} \\
= & 0.3136+0.00002+0.0008=0.31492 \\
D_{4}^{-} & =\sqrt{(0.66-0.1)^{2}+(0.022-0.017)^{2}+(0.05-0.022)^{2}} \\
= & 0.3136+0.00002+0.0008=0.31492 \\
D_{5}^{-} & =\sqrt{(0.1-0.1)^{2}+(0.022-0.017)^{2}+(0.05-0.022)^{2}} \\
& =0+0.00002+0.0008=0.00082
\end{aligned}
$$

\begin{tabular}{|c|c|c|c|c|c|c|}
\hline No & Nama & $\begin{array}{c}\text { Pangkat } \\
\text { dan } \\
\text { Golongan }\end{array}$ & $\begin{array}{l}\text { Nilai } \\
\text { SKP }\end{array}$ & $\begin{array}{c}\text { Angk } \\
\text { a } \\
\text { Kredit }\end{array}$ & $\begin{array}{l}\text { Nilai } \\
\text { Hasil }\end{array}$ & $\begin{array}{c}\text { Rengki } \\
\text { ng }\end{array}$ \\
\hline 1 & ADR & $\begin{array}{l}\text { Penata } \\
\text { Muda Tk I / } \\
\text { III.b }\end{array}$ & $\begin{array}{c}92.0 \\
0\end{array}$ & $\begin{array}{c}261.1 \\
7\end{array}$ & $\begin{array}{c}0.314 \\
1\end{array}$ & 2 \\
\hline 2 & IND & $\begin{array}{l}\text { Pengatur / } \\
\text { II.C }\end{array}$ & $\begin{array}{c}86.5 \\
5\end{array}$ & 180 & $\begin{array}{c}0.000 \\
8\end{array}$ & 4 \\
\hline 3 & ALD & $\begin{array}{l}\text { Penata Tk I } \\
\text { / II.D }\end{array}$ & $\begin{array}{c}92.0 \\
0\end{array}$ & $\begin{array}{c}221.9 \\
5\end{array}$ & 1 & 1 \\
\hline 4 & SRI & $\begin{array}{l}\text { Pengatur / } \\
\text { II.C }\end{array}$ & $\begin{array}{c}91.2 \\
4\end{array}$ & 255 & 1 & 1 \\
\hline 5 & $\mathrm{NOF}$ & $\begin{array}{l}\text { Penata / } \\
\text { III.C }\end{array}$ & $\begin{array}{c}92.0 \\
0\end{array}$ & 255.8 & $\begin{array}{c}0.001 \\
3\end{array}$ & 3 \\
\hline
\end{tabular}

5. Menghitung Nilai Preferensi setiap Alternatif

$$
\begin{aligned}
& v_{i}=\frac{D^{i}}{D^{-}+D^{+}} \\
& v_{1}=\frac{0.0008}{0.0008+0.3141}=0.3141 \\
& v_{2}=\frac{0.3136}{0.3136+0.00082}=0.00082 \\
& v_{3}=\frac{0.3149}{0.3149+0}=1 \\
& v_{4}=\frac{0.31492}{0.31492+0}=1 \\
& v_{5}=\frac{0.00082}{0.00082+0.0013}=0.0013
\end{aligned}
$$

\section{Hasil Perengkingan}

Berdasarkan Hasil Alternatif dan Kriteria Dapat dilihat pada Tabel 12.

Tabel 12. Hasil Akhir dan Perangkingan

\section{Kesimpulan}

Dengan mengimplementasikan metode TOPSIS untuk mengidentifikasi penentuan prioritas usulan kenaikan jabatan fungsional pegawai maka sangat memudahkan dalam pencarian kenaikan jabatan fungsional pada Politeknik Negeri Padang dengan hasil tidak jauh berbeda antara program dan hitungan manual.

\section{Daftar Rujukan}

[1] Murti, A. C., \& Chamid, A. A. (2019). Sistem Pendukung Keputusan untuk Penentuan Prioritas Pemberdayaan Masyarakat melalui Perilaku Hidup Bersih dan Sehat Menggunakan Metode Topsis. Jurnal Teknologi Informasi dan Ilmu Komputer, $\quad 6(5) . \quad$ DOI: http://dx.doi.org/10.25126/jtiik.2019651049 .

[2] Santiary, P. A. W., Ciptayani, P. I., Saptarini, N. G. A. P. H., \& Swardika, I. K. (2018). Sistem Pendukung Keputusan Penentuan Lokasi Wisata dengan Metode Topsis. Jurnal Teknologi Informasi dan Ilmu Komputer, 5(5). DOI: http://dx.doi.org/10.25126/jtiik.2018551120 .

[3] Gunawan, C. E. (2020). Penerapan Metode TOPSIS untuk Pengangkatan Karyawan Kontrak Menjadi Karyawan Tetap (Studi Kasus: PT Hanuraba Sawit Kencana). JIKO (Jurnal Informatika dan Komputer), 3(1), 42-50. DOI: http://dx.doi.org/10.33387/jiko.v3i1.1722 .

[4] Doni, R., Amir, F., \& Juliawan, D. (2019). Sistem Pendukung Keputusan Kenaikan Jabatan Menggunakan Metode Technique for Order Preference by Similarity to Ideal Solution (TOPSIS). Prosiding Seminar Nasional Riset Information Science (SENARIS), 1. DOI: http://dx.doi.org/10.30645/senaris.v1i0.9

[5] Hartini, H., \& Tan, F. (2018). Sistem Pendukung Keputusan Kenaikan Jabatan Fungsional dan Pangkat Dosen. Jurnal Sisfokom (Sistem Informasi dan Komputer), 7(1). DOI: https://doi.org/10.32736/sisfokom.v7i1.287 .

[6] Amida, S. N., \& Kristiana, T. (2019). Sistem Pendukung Keputusan Penilaian Kinerja Pegawai dengan Menggunakan Metode Topsis. JSAI (Journal Scientific and Applied Informatics), 2(3). DOI: http://jurnal.umb.ac.id/index.php/JSAI/article/view/415

[7] Febrian, T. B., \& Simangunsong, A. (2020). Decision Support System Employee Performance Appraisal Method Using TOPSIS. Journal of Computer Networks, Architecture and High Performance Computing, 2(2), 307-312. DOI: https://doi.org/10.47709/cnapc.v2i2.412 .

[8] Hamid, A., \& Midyanti, D. M. (2019). Penerapan Metode Topsis dalam Penentuan Skala Prioritas Rehabilitasi Jaringan Irigasi Daerah Ketiat B Bengkayang. Simetris: Jurnal Teknik Industri, Mesin, Elektro dan Ilmu Komputer, 10(1), 295-302. DOI: https://doi.org/10.24176/simet.v10i1.2979 .

[9] Irsan, M. (2018). Implementasi Aplikasi Sistem Pendukung Keputusan Kenaikan Jabatan Pegawai Negeri Sipil (Pns) Menggunakan Metode Weight Product Pada Bagian Protokol dan Dokumentasi Setda Kota Depok. Faktor Exacta, 11(1). DOI: http://dx.doi.org/10.30998/faktorexacta.v11i1.2344

[10]Hertyana, H. (2019). Sistem Pendukung Keputusan Seleksi Pemilihan Perguruan Tinggi Menggunakan Metode Topsis. Jurnal Pilar Nusa Mandiri, 15(1), 97-102. DOI: https://doi.org/10.33480/pilar.v15i1.223 .

[11]Sunarti, S. (2019). Employee Performance Assessment for Promotion with the Topsis Method in Senayan Apartments $\begin{array}{llll}\text { Jakarta. } & \text { SinkrOn, } & 3(2) . & \text { DOI: }\end{array}$ https://doi.org/10.33395/sinkron.v3i2.240 .

[12] Minouei, A., \& Zaidi abd Rozan, M. (2018). University Entrepreneurship Center Identity Factors Prioritization Using TOPSIS Method. International Journal of Engineering \& Technology, $\quad 7(3)$. http://dx.doi.org/10.14419/ijet.v7i3.12252 .
DOI: 
[13]Lestari, Y. D., \& Mardiana, M. (2020). Decision Support System For Determining the Best College High Private Using Topsis Method. SinkrOn, 4(2). DOI https://doi.org/10.33395/sinkron.v4i2.10235 .

[14] Govil, N., Tripathi, A., \& Kumari, V. (2019). Identification of Best Indian Entry-Level Segment SUV through TOPSIS Method. International Journal of Recent Technology and Engineering (IJRTE), 8(4), 8237-8240. DOI http://dx.doi.org/10.35940/ijrte.d8914.118419 .

[15] Aktavera, B., Defit, S., \& Sumijan, S. (2020). Sistem Penunjang Keputusan dalam Penentuan Prioritas Pembanguanan Menggunakan Metode Trus Base dengan Topsis. Jurnal Informatika Ekonomi Bisnis, 2(4), 138-143. DOI: https://doi.org/10.37034/infeb.v2i4.76 .

[16]Purba, E., Vinsensia, D., \& Utami, Y. (2018). Decision Support System For Determining Best Homeroom Teacher With Topsis Method In Mis Nurul Huda Pantai Labu. Zero: Jurnal Sains, Matematika dan Terapan, 2(1).

[17] Rahim, R., Supiyandi, S., Siahaan, A. P. U., Listyorini, T., Utomo, A. P., Triyanto, W. A., Irawan, Y., Aisyah, S.,
Khairani, M., Sundari, S., \& Khairunnisa, K. (2018). TOPSIS Method Application for Decision Support System in Internal Control for Selecting Best Employees. International Conferance on Statistics, Mathematics, Teaching, and Research.

[18]Paydar, M., \& Ghahremani, M. (2019). Identification And Ranking of Factors Affecting Financial Health and SelfEfficacy of Manpower In The Shahid Foundation of The West Azerbaijan Affairs Using TOPSIS Model. International Academic Journal of Business Management, 6(1), 233-248. DOI: http://dx.doi.org/10.9756/IAJBM/V6I1/1910025 .

[19] Tasman, A., \& Simanjorang, R. M. (2020). Decision Support System Honorary Employee Performance Appraisal with TOPSIS method the Public Works Department and Spatial Deli Serdang. Journal of Computer Networks, Architecture and High Performance Computing, 2(2),250-258.

[20]Palasara, N. D., \& Baidawi, T. (2018). Penerapan Metode Topsis Pada Peningkatan Kinerja Karyawan. Jurnal Informatika, 5(2), 287-294. DOI: https://doi.org/10.31294/ji.v5i2.4234 